\title{
A Martyred Teacher and a Teacher of the Church: Two Recent Editions of Neo-Latin Jesuit Plays from Germany
}

Andreas Abele, ed. and transl., Matthäus Rader SJ, Drama de Divo Cassiano: Drama über den Heiligen Cassian. Die neulateinische Bibliothek, 5. Heidelberg: Universitatsverlag Winter, 2021. Pp. 230. Hb, € 39.00.

Joachim Werz, Bernhard von Clairvaux auf der Bühne der Jesuiten: Edition und Übersetzung der "Divi Bernardi Tragicomœdia" aus dem Kölner Gymnasium Tricoronatum. Klosterwelten, 2. Münster: Aschendorff 2021. Pp. 255. Hb, € 39.oo.

The production of Jesuit drama in the German-speaking countries, by and large the territories of the Holy Roman Empire, has been a subject of scholarly research for decades. But while names of plays and theatre sheets have been thoroughly collected and analyzed (the most important collection being Das Jesuitendrama im deutschen Sprachgebiet: Eine Periochen-Edition, ed. Elida Maria Szarota. 4 parts in 7 vols. [Munich: Fink, 1979-87]), modern editions of Jesuit plays, however, accompanied by translations and necessary commentaries, are still relatively scarce. Recent exceptions are: Andreas Abele, Jeremias Drexel SJ: Iulianus Apostata Tragoedia: Edition, Übersetzung und Kommentar (Berlin: de Gruyter 2018); Sieglind Stork, Das Theater der Jesuiten in Münster (1588-1773) mit Editionen des "Petrus Telonarius" von 1604 und der "Coena magna" von 1632: Übersetzung der Dramen von Christian Peters (Münster: Aschendorff 2013). However, the influential plays by the Cologne professor, literary theorist, and spiritual writer Jacob Masen, for instance, still await a contemporary edition. Only three of them are available in a somewhat outdated edition by Michael C. Halbig, The Jesuit Theater ofJacob Masen: Three Plays in Translation with an Introduction (New York: Lang 1987). But now these two editions promise fruitful insights into subjects and practices of early modern Jesuit theatre.

The first one is Andreas Abele's edition of Matthäus Rader's (1561-1634) Drama de Divo Cassiano (1594). After a concise biographical sketch of Rader's life and influence on Jesuit culture particularly in Bavaria (1-3), the editor sets out to define the functions of early modern Jesuit theater. As goals, he stresses the improvement of the pupils' language skills and their demeanor on stage 
and the implications of representation, the Catholic faith in general, and the specific aims advanced by the Society of Jesus during their often very elaborate Counter-Reformation performances (4-14). As far as faith and moral purposes are concerned, Abele compellingly draws on St. Ignatius's Spiritual Exercises and their key concepts of compositio loci and applicatio sensuum that organize the individual's meditation by means of controlled imagination and sensual impressions. On the Jesuit stage as the outward complement of the meditating's inner stage, "the same effect of strengthening the faith as in the spiritual exercises can be achieved" (12, my translation). The following historical overview of the Jesuit theater and its practice in terms of performances, the role of music, elaborate stage settings, and the periochae (theatre sheets), which were intended to convey the plays' Latin text to a vernacular lay audience, bears scarcely new information but works as a concise introduction for students and scholars not intimately acquainted to the subject.

A thorough editorial description leads to the play at hand, Rader's Drama de Divo Cassiano, performed in the Munich college in 1594 and again in 1597 in Regensburg. Abele's reconstruction from the few available sources shows that Rader's original three-act-version was supplemented by the Jesuit Wolfgang Starck (1554-1605) who added another act in order to adapt the play to the specific situation in Regensburg: In the added scenes, Cassian practically appears as a spiritual patron for the Regensburg bishop and cardinal Philipp of Wittelsbach who started out on a journey to Rome a few days after the play was performed (25). Further information is given by the editor, so that readers can appreciate and analyze the following play more comprehensively: a plot summary (32-37), a brief but insightful chapter on the legendary tradition concerning Cassian, from Prudentius's Peristephanon up to Rader's own hagiographical compendium Bavaria Sancta (26-32), and a third chapter offering "contexts and interpretative approaches" (37-45). The latter is important since it situates the play about a "teacher-martyr" from late antiquity in the context of reflections about teachers and teaching practices within the Society of Jesus. Abele aligns verses from Cassianus's act I with quotations from other Jesuit plays in which teachers complain about the base understanding and the lacking discipline of their pupils - and vice versa (37 f.). In this respect, Abele's edition also offers material to a previously underrated research question, namely the reflection of Jesuit education and everyday school work in Jesuit drama and poetry (see one example from the field of elegiac poetry: Jost Eickmeyer, "Rut und die Lehren für den Papagei:Jesuitische Latinität zwischen Intermedialität, Didaktik und poetischem Wettstreit mit den Alten; Ein Essay über Johannes Bisselius' Deliciae Aestatis III,Xxx und XxxI," in Prata Florida: Neue Studien anlässlich des dreißigjährigen Bestehens der Heidelberger "Sodalitas Neolatina" 
[1988-2018], ed. Wilhelm Kühlmann and Ladislaus Ludescher [Heidelberg: Mattes 2020], 147-88). Against this backdrop the martyred teacher Cassian, knifed to death by his own pupils, not only becomes a martyr of Christian faith but is also construed as an ideal Jesuit teacher avant la lettre, as Abele's comparisons of Cassian's monologues with passages from the Ratio studiorum and other key texts of Jesuit education demonstrate (41-44).

A very different teacher-a medieval teacher of the church-appears on stage in another recently edited play written at the famous Gymnasium Tricoronatum in Cologne. Saint Bernard of Clairvaux is the main character of a play preserved in a manuscript of notes from theater rehearsals and/or performances at the Cologne school. The editor Joachim Werz prefixes his bilingual edition with a much longer introductory part than Abele. This is due to the fact that the dialogues and plays of the Cologne Jesuits, an ample production between 1561 and 1771 , have been neglected by scholars since 1928. Two seminal studies were published: Paul Bahlmann, Die Jesuitendramen der niederrheinischen Ordensprovinz (Leipzig: Harrassowitz, 1896), and Josef Kuckhoff, "Das erste Jahrhundert des Jesuitenschauspiels am Tricoronatum," in Jahrbuch des Kölner Geschichtsvereins 10 (1928): 1-49. This lack of interest for one of the most important Jesuit institutions in the Lower Rhine province caught Werz's attention. As a result, he begins his edition with a short survey of the current research on Jesuit theatre in general (11-21) and a variety of resources pertinent to the Jesuit theatre practice in early modern Cologne. They consist of a chronological outline of the history of the Gymnasium Tricoronatum, the most important Jesuit school in Cologne where influential Jesuits like Peter Canisius and Friedrich Spee taught (23-27); an important chronological survey by title of the Jesuit plays written and/or performed in Cologne $(28-32)$ and finally a detailed repertory of the listed plays (38-104), featuring: title, date, and place of the performance (if known), name(s) of the author and the director ("choragus"), the occasion of the performance, further information about actors, guests or other pertinent circumstances, a list of the plays' manuscripts (if extant) as well as their theatre sheets, and finally research literature treating the individual play (if there is any). These resources, and the repertory in particular, break the ground for further research into Jesuit theatre practices in Cologne, its subjects, occasions and means from the early days of the Society by the Rhine River until the late eighteenth century. They might even work as a sample for a future online database of Jesuit plays in the German-speaking countries, if any scholar or group of scholars may get any funding for such an endeavor.

As for the plays presented in these new editions, there are multiple differences. While the Drama de Divo Cassiano can be attributed to specific authors, 
the author(s) of the Divi Bernardi Tragicomoedia remain unknown, as is in the case with most Jesuit plays known or extant today. While the two performances of Rader's play can be dated and, in case of the reproduction in Regensburg, even linked to a specific occasion, we can only conjecture about the writing and performance of the anonymous Cologne play sometime between 1574 and 1640 (cf. 107, 123). While the Cassianus play is preserved as a whole, the Cologne manuscript consists of only two of probably three acts (Werz, 107). While the subject of Cassian's martyrdom is closely linked to the realm of school life and educational issues (as suggested above), and at times uses the comical effects of rather absurd situations in a chaotic classroom (Rader, 39), the subject of St. Bernard deals very seriously with the call to Christian conversion, to abandoning the world (and parts of his family) in favor of a "life of prayer, penitence and chastity" (Werz, 115). Both main characters have to make a decision concerning the salvation of their souls. This decision with the implication of free will, marks a general and theologically decisive contrast to contemporary Protestant school plays: an individual's free will in accordance with Christian ethics can only be promulgated against the backdrop of a Catholic notion of justification (cf. Abele's correct assumption in Rader, 14). But while it is Cassian's death that becomes a testimony for Christian steadfastness in the face of adversity, even an emulation of Christ (Rader, 40), Bernard's decision to join the Cistercian order transforms his life into a life of service to the church whose impact on the Cistercian as well as Jesuit culture can hardly be overrated (Werz, 109-17). This difference can not only be attributed to the generic contrast between "drama" (in modern terms, tragedy), whose main character dies in the end, and "tragicomodia," whose main character defies adversities and survives (Werz, 107-9). The difference also pertains to the intended audience and its "profession": Cassianus embodies the ideal Jesuit teacher as well as a historical martyr in order to drive teachers as well as students to emulate this ideal or obey it. Bernard embodies the Ignatian discretio spirituum by following a clerical, monastic vocation in order to encourage Jesuit priests, as well as future clerics among the pupils, to live and act out their "confessional identity" (if the modern term may be applied here). It is no coincidence that the "discerning of the spirits" itself is rooted in Bernardian spirituality as rightfully mentioned by Werz (115 f.).

These differences in content and intended impact of the plays become clearer as the ways in which both editors present their respective text. Both editors draw from the only extant manuscript so there is no need for extensive critical apparatus. Abele, as a classicist by trade, offers a "normalized" Latin text dissolving all ligatures and abbreviations and adapting uses of early modern orthography (concerning e.g. "u"/"v," “y" instead of "ii" or "u," "ch" to "c," etc.) 
and punctuation to a modern standard (see Rader, 45 f.) — the "Teubner standard," one might say. Werz, however, a theologian by trade, alters the text as presented in the manuscript as little as possible, dissolving only select abbrevi-

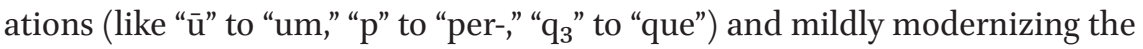
punctuation (Werz, 123-25). Both editors add the names of characters entering the stage at the beginning of a scene, a reasonable addition in order to give the reader some orientation. Both offer a commentary with information about biblical and historical figures, quotations from and allusions to texts from classical antiquity and other sources. Only Werz chooses to present his commentary in footnotes below the German translation (129-221), Abele puts it as a separate chapter at the end of the bilingual edition (187-211). In the former case, the readers can immediately consult the commentary without having to leaf through the book, in the latter case the commentator has more space to give more detailed and additional information pertinent to a specific aspect of the play.

These differences in editorial principle can very well be disputed one way or the other, in general they show the ongoing dependency of editorial practice from the respective editor's academic field. A standardization of these principles in the field of neo-Latin scholarship does not seem likely even if it should be desirable.

The German translations, although probably of less interest to anglophone readers, are very solid and in both cases suit the subject of the play. Abele uses more colloquial and idiomatic phrases in the schoolroom-scenes of the first act, and later changes to a more solemn wording for the scenes of Cassian's martyrdom (act III) and his appearance in heaven (act IV). Werz's translation remains very close to the Latin text, and even tries to represent the line-breaks of the original iambic trimeters (129 f.). This seems to be a rather odd approach, since Werz's is not a poetic translation, so the readers have to "jump" the lines of a prose text quite haphazardly.

Notwithstanding all these differences, both editions bear witness to the contemporary interest in and standards of bringing Jesuit drama and its various historical, literary, and theological contexts into the academic discourse. Werz's edition may be called more scholarly, whereas Abele's presentation of the text may also be intended for an actual modern performance, possibly in a German school. All in all, both publications also represent the spectrum of editing neo-Latin drama today. They shed light on the practice of early modern Jesuit theatre in two of the most prolific literary regions of the German provinces, Cologne and Bavaria, on their differences as well as similarities. Hopefully, these publications will instigate more and similar editions in the 
field as well as further research on Jesuit poetry in Cologne, Munich, and elsewhere.

\section{Jost Eickmeyer}

Centre for the Study of Manuscript Cultures, University of Hamburg, Hamburg, Germany jost.eickmeyer@uni-hamburg.de 